\title{
MOLECULAR IDENTIFICATION OF THREE STORED PRODUCT INSECT SPECIES ON DRIED FRUITS AND THEIR CONTROL WITH THE USE OF SOME AQUEOUS PLANT EXTRACTS
}

\author{
Sahand K. Khidr *, Waran Nooraldeen. A. Agha, and Adil H. Amin \\ Dept. of Plant Protection, College of Agriculture, Salahadin University, Erbil, Kurdistan Region, Iraq - \\ sahand_kkh@yahoo.com
}

\begin{abstract}
:
Mortality of three insects; red flour beetle (Tribolium castaneum Herbst), khapra beetle (Trogoderma granarium Everts) and sawtoothed grain beetle (Oryzaephilus surinamensis $(\mathrm{L}$.)) were evaluated via some aqueous plant extracts. The identification of three examined insects was carried out via designing specific primers for each aforementioned species with the use of PCR technique. The toxicity of aqueous plant extracts; eucalyptus (Eucalyptus camaldulensis Dehnh), mint (Mentha canadensis L.) and myrtle (Myrtus communis L.) at three dosages (12500, 25000 and 50000) ppm for 1, 2, 3 and 7 days were tested for their insecticidal activity against examined adults on dried fruits. Percentage mortality of insect was increased with an increase of doses and exposure times, whereas, not influenced significantly by the fruit types. T. castaneum was the most susceptible species, followed by $T$. granarium and $O$. surinamensis. Likewise, LC $_{50}$ values were $(3887.25,10816.34 \& 22763.48)$ on red flour, khapra \& sawtoothed grain beetles respectively via using eucalyptus aqueous extract after 7 days on black raisin. While, higher doses required in order to kill fifty percentage of the population via myrtle aqueous extract and thus the $\mathrm{LC}_{50}$ values increased to $(14726.86,18421.43 \&$ 39016.78) on the three aforementioned species respectively.
\end{abstract}

KEYWORDS: Concentration, LC 50, Dried Fruits, DNA Extraction, Mortality, Polymerase Chain Reaction.

\section{INTRODUCTION}

Dried fruits are among the healthiest dietary that primarily have been valued for long term stability and their sweetness that consist of refined sugar, rich source of minerals, fibers and proteins (Gyurova and Enikovam 2014). Dried fruits are also consider as an excellent resource of polyphenols and phenolic acids, that comprise the largest group of plant bioactive compounds in the diet and appear to be responsible for the health benefits (Carughi et al., 2016). Dried figs include natural sugar substance, carbohydrates as a major content $(73.50 \%)$, fat content around $(0.56 \%)$, protein (4.67\%), fibre $(3.68 \%)$ and encompass essential minerals (e.g. copper, manganese, magnesium, potassium and calcium) (Gyurova and Enikovam 2014; Soni et al., 2014). Whereas, raisins not only encompass important ingredients but also are consumed more than other types of dried fruits. In addition, cereal grains consider vital food source for human nutrition and have played an important role in building human civilization for thousands of years. Globally, wheat and rice crops play a significant role in economic stability throughout the world and approximately 50\% of consumed calories by the whole populations count on the aforementioned crops (Poehlman and Sleper, 1995; Chowdhry et al., 1998; Varshney et al., 2006; Gnanamanickam 2009; Zuzana et al., 2009). Thus, the demand for enhanced food production is as topical as ever due to human population growth (Zeigler and Mohanty, 2010; Ronald, 2011). High proportions of produce each year around $10-15 \%$ of the total grain production might be lost during storage processes due to insects and rodent pests in America (Sharma and Choudhary, 2008; Hill, 1990), and the annual losses can be even higher about $30 \%$ in Africa and
Asia (Hill, 1990). Insect infestation would result in the loss of nutritive value of dried fruits, reduced seed germination, and also causes changes in chemical components such as increase in moisture, free fatty acid levels and decrease in protein contents of grains (Rees, 2004 ; Das et al., 2013).

The most widespread and destructive insects of stored products (i.e. cereals and dried fruits) are red flour beetle Tribolium castaneum Herbst, Khapra beetle Trogoderma granarium Everts and saw toothed grain beetle oryzaephilus surinamensis (L.) (Weston and Rattlingourd, 2000; Campbel et al., 2004; Rees, 2004; Mishra et al., 2012). Since it is difficult to identify indistinctive species on the basis of external morphological characteristics alone, especially both red flour beetle and the confused flour beetle are sympatric and morphologically similar stored-product pests, and the latter is named because of confusion over its identity as it is so similar to the former (Walter, 1990). Hence, molecular identification of species is an appropriate alternative to conventional taxonomical method (Nowaczyk et al., 2009; Castalanelli et al., 2011; Sorvari et al., 2012; Ming et al., 2014)

Furthermore, great deal of attention has been given for the adoption of improved post-harvest technology. Various methods and strategies were implemented in order to control stored product insects such the traditional chemical insecticides. Fumigants are mostly used against stored-grain insect pests because of their broad activity spectrum as well as their penetrating power on the treated products. Although using fumigants (e.g. methyl bromide and phosphine) in large scale for a long period of time might cause the appearance of resistant strains, environmental pollution, toxicity to non-target organisms, and pesticide residues on treated stored products making pesticide application a poor long term solution that raise global concern about food safety (Zettler \& Cuperus 1990;

\footnotetext{
* Corresponding author
} 
Stephan, 2003; Benhalima et al., 2004; Bughio and Wilkins, 2004).

Hence, plant extracts which known as biocide or green pesticides can be a substitute source of chemical pesticide due to their safe, eco- friendly, inexpensive, easy to use with more compatible properties (Risha et al., 1990; Susha and Kamavar, 1993). Secondary compounds from plants include alkaloids, terpenoids, phenolic, flavonids, sesquiterpenes, Iimonoides and other chemicals might affect insects in various manner. They have potential to disrupt major metabolic pathways and cause fast death, act as attractants, deterrents and antifeedants (Alford et al., 1987; Sarmamy et $a l ., 2011$ ). Different types of plant extracts have been used as biocides either to eliminate or minimize the yield loss due to pests (Alford et al., 1987; Tayoub et al., 2012; Rahman et al., 2016).

Due to the lack of sufficient studies on the use aqueous plant extracts in the fight against stored product insects especially on dried fruits this study has undertaken in order that aqueous botanical extracts can be used in broader ranges and the technique would found their way into more practical use as safe natural insecticides. Hence, the present study aimed to investigate the toxic impact of aqoues plant extracts from eucalyptus Eucalyptus camaldulensis Dehnh, mint Mentha canadensis L. and myrtle Myrtus communis L. on the mortality of Tribolium confusum, Trogoderma granarium and oryzaephilus surinamensis adult stage as well as designing specific primers for the aforementioned insects in order to be available for further studies.

\section{MATERIALS AND METHODS}

\subsection{Insect cultures}

The experiment was conducted in both biotechnology and high education laboratories of Agriculture College at Salahaddin university-Erbil. Mass cultures of red flour beetle Tribolium castaneum Herbst (Tenebrinidae: Coleoptera) were maintained under standard food medium of wheat flour supplemented with 5\% dry yeast powder (Singh and Prakash 2015). Khapra beetle Trogoderma granarium Everts (Dermestidae: Coleoptera) was reared on a diet consists of whole wheat and broken wheat (Khair, 2015), whereas saw-toothed grain beetle Oryzaephilus surinamensis (L.) (Silvanidae: Coleoptera) were maintained on rice culture (Yousif, 2012).

The diets with insects were placed in large plastic $(600 \mathrm{ml})$ capacity, covered with fine mesh cloth which simultaneously allow ventilation and prevent insects from escaping. All cultures were maintained in incubator at $\left(30 \pm 2^{\circ} \mathrm{C}\right)$ temperature and $(60 \pm 2)$ relative humidity.

\subsection{Experiment 1: Insect identification through molecular based method (PCR)}

Leave one lines blank, then Type "ABSTRACT:" flush left in bold Capitals. Start now with a concise Abstract (100 - 200 words) which presents briefly the content and very importantly, the news and results of the paper in words such to be understandable also to non-specialists.

Table (1): Primers used to confirm the identification of insect species

\begin{tabular}{|c|c|c|c|c|c|c|c|}
\hline \multicolumn{8}{|c|}{ Tribolium castaneum Herbst } \\
\hline Name & (Ps)bp & Length & Sequence $\mathbf{F}$ & length & Sequence $\mathbf{R}$ & $\mathbf{T M}\left({ }^{\circ} \mathbf{C}\right)$ & References \\
\hline Tcas-1 & 120 & 21 & $\begin{array}{l}\text { 5'-CTTCCAGGAT } \\
\text { TTGGCATAATC-3' }\end{array}$ & 21 & $\begin{array}{l}\text { 5'-CAAAACCTAA } \\
\text { GAGCCCAATTG-3' }\end{array}$ & 57 & This study \\
\hline AKK-1 & 120 & 20 & $\begin{array}{l}\text { 5'-GGGTGTGTAC } \\
\text { CGCTCAGTTA-3' }\end{array}$ & 20 & $\begin{array}{l}\text { 5'-GGCGAATTGG }^{\prime} \\
\text { GAATATTGAA-3' }\end{array}$ & 57 & Li et al, 2008 \\
\hline TconfA & 150 & 20 & $\begin{array}{c}\text { 5'GTGTATCTACA } \\
\text { CACACACAC-3' }\end{array}$ & 20 & $\begin{array}{l}\text { 5'GAACCGCCAA } \\
\text { TATTGAGTTG-3' }\end{array}$ & 55 & Li et al, 2008 \\
\hline TconCOI & 100 & 21 & $\begin{array}{c}\text { 5'CTTCCTGGATTC } \\
\text { GGAATAATC - } 3^{\prime}\end{array}$ & 21 & $\begin{array}{l}\text { 5'CGAACCCTAG } \\
\text { TAATCCAATTG-3' }\end{array}$ & 57 & Li et al, 2008 \\
\hline \multicolumn{8}{|c|}{ Trogoderma granarium Everts } \\
\hline T gra-1 & 169 & 20 & $\begin{array}{l}5^{\prime}-\mathrm{TAGACACACG} \\
\text { GGCCTACTTC -3' }\end{array}$ & 21 & $\begin{array}{c}\text { 5'CCTGTTAGTCCT } \\
\text { CCTAGGGTG -3' }\end{array}$ & 61 & This study \\
\hline T gra-2 & 193 & 20 & $\begin{array}{c}\text { 5'-ATCCACCTTTA } \\
\text { TCCGCCAAC -3' }\end{array}$ & 19 & $\begin{array}{c}\text { 5'AGGGCGGTGA } \\
\text { TTGCTACTG -3' }\end{array}$ & 59 & This study \\
\hline $\mathbf{T}$ inc-3 & 154 & 20 & $\begin{array}{c}\text { 5'-TGGTTGGGGTG } \\
\text { ATTGGAAAA-3' }\end{array}$ & 23 & $\begin{array}{c}\text { 5'-CGCAAACTCTC } \\
\text { CTTTCGATTAGA- } \\
3^{\prime}\end{array}$ & 58 & This study \\
\hline T var-4 & 235 & 20 & $\begin{array}{c}5^{\prime} \text { TTTGACTGTGC } \\
\text { GAAGGTAGC-3' }\end{array}$ & 20 & $\begin{array}{c}\text { 5'-ATTTCCCAATC } \\
\text { ACCCCAACC-3' }\end{array}$ & 58 & This study \\
\hline \multicolumn{8}{|c|}{ Oryzaephilus surinamensis (L.) } \\
\hline O sur-1 & 223 & 21 & $\begin{array}{l}\text { 5'ACAGAACTAGG } \\
\text { AACAGCAGGT -3' }\end{array}$ & 20 & $\begin{array}{l}\text { 5'-AGAGAAGGGA } \\
\text { GATTGAGGGA -3' }\end{array}$ & 59 & This study \\
\hline O sur-2 & 268 & 21 & $\begin{array}{l}\text { 5'ACAGAACTAGG } \\
\text { AACAGCAGGT -3' }\end{array}$ & 20 & $\begin{array}{c}\text { 5'CTGTTCATCCTG } \\
\text { TTCCTGCC - } 3^{\prime}\end{array}$ & 59 & This study \\
\hline
\end{tabular}


2.2.1 Design and preparation of primers: Species specific primer pairs were designed by Primer 3 (Rozen \& Skaletsky 2000) (Table 1). To prepare a stock of $100 \mathrm{pmol} /$ $\mu 1$ from the ordered primers, Sigma molecular biology grade water was added with the volume that was reported in the accompanying information. After vortexing and spinning, tubes were placed on ice for $30 \mathrm{~min}$ and to produce a $10 \mathrm{x}$ primer stock; $1 \mu \mathrm{l}$ of the stock was mixed with $9 \mu \mathrm{l}$ SDW for the both Forward \& Reverse primers into separate tubes on ice. After that they were kept in a freezer at $-20^{\circ} \mathrm{C}$.

2.2.2 DNA extraction: A sample size of 300 adults divided into six pooled samples of 50 individuals was used for the test; each two pooled samples represent one type of the studied insect. Pooled samples of 50 individuals were immersed into liquid nitrogen and then crushed into a fine powder using a pre-cooled sterilized mortar and pestle. The Genomic DNA was extracted from whole adults by following methods given in Allen et al. (2006) with some modification, before elution/resuspension into $25 \mathrm{ul}$ of Tris-EDTA buffer in the final step and stored in freezer at $-20^{\circ} \mathrm{C}$ until it used.

2.2.3 Polymerase chain reaction (PCR): DNA was amplified using thermocycler Hybaid PCR machine (Applied Biosystems, 96-Well Fast Thermal Cycler)) in 20 $\mu 1$ reaction volume. The reaction composed of $10 \mu 1$ of PCR master mix (Gene Direx); $3 \mu$ l of DNase RNase free water (Bioneer); 3 $\mu 1$ of DNA template and $2 \mu 1$ of both forward and reverse primers (Macrogen, Ligo, USA) to make a total volume of 20 $\mu \mathrm{l}$ as in the table (2), reaction in negative control composed of all components except DNA template. PCR reactions were run for 3 min at $94^{\circ} \mathrm{C}$ (initial denaturation), followed by 35 cycles of $1 \mathrm{~min}$ at $94^{\circ} \mathrm{C}$ (denaturation), $1 \mathrm{~min} 55-65^{\circ} \mathrm{C}$ (annealing) and $72^{\circ} \mathrm{C}$ for $1 \mathrm{~min}$ (extension). The last step was $72^{\circ} \mathrm{C}$ for 7 minutes (Final Extension) (Table (1)).

2.2.4 Agarose gel electrophoresis: Agarose gel prepared by adding $0.75 \mathrm{gm}$ agarose powder (Agarose M, Bio Basic Canada INC.) to $50 \mathrm{ml}$ of $1 \mathrm{x}$ TBE (Tris- Borate- EDTA) buffer, then carefully dissolved by microwave oven until all the particles were dissolved. After the solution cooled down, $5 \mu$ ethidium bromides was added and mixed gently. The gel poured into to the tray of which the comb inside it and sterilized tip was used to remove the bubbles around the comb tips and on the gel surface. After the gel had set, the tape around the tray and the comb was carefully removed to leave the well behind it to allow appropriate loading of PCR products inside it.

Later, gently $10 \mu \mathrm{l}$ volume of each sample were loaded onto a submerged gel that consisted of a $1.5 \% \mathrm{w} / \mathrm{v}$ concentration of agarose. Appropriate size marker, $8 \mu 1$ of 2-log (100-3000 bp) DNA ladder H3 RTU (Gene Direx) was loaded in the first well of the gel by micro pipette, then the gel was run at $60 \mathrm{~V}$ for approximately 1 hour and examined under UV light (UV Transilluminator Biostep-UST-20M-8K). The photo was taken by using digital camera (Canon; Japan).

\subsection{Experiment 2: Plant extracts to control examined insects}

2.3.1 Preparation of aqueous extracts: Fresh leaves of myrtle Myrtus communis L., eucalyptus Eucalyptus camaldulensis Dehnh and mint Mentha Canadensis L. were collected in ministry of high education and college of agriculture from Hawler region. Leaves of these plants were washed carefully with water, air dried in shade and ground into fine powder through using electric grinder (Germany). $50 \mathrm{~g}$ dry powder from each plant were mixed with $500 \mathrm{ml}$ distilled water to prepare a $10 \%$ stock solution. The solution were kept overnight then filtered with muslin cloth and stored in refrigerator prior to use (Abdulhay, 2012). Stock solution were then serially diluted to obtain the desired concentrations of $(5,2.5$ and 1.25$) \%$ that equivalent to $(50000,25000 \& 12500) \mathrm{ppm}$ subsequently.

2.3.2 Bioactivity of the extracts: A sample size of 720 individuals was used for the experiment. We examined the toxicity of the three afore mentioned plant extracts on a total of 240 adults of either species (Tribolium castaneum, Trogoderma granarium \& Oryzaephilus surinamensis). Three replicates each consist of 10 insects mixed with either black raisin or fig (10 insects/ $20 \mathrm{~g}$ dried fruits) were sprayed with 50000, 25000 \& $12500 \mathrm{ppm}$ by using syringe inside $250 \mathrm{ml}$ plastic container that later covered by a muslin cloth. All treatments were placed in the incubator at the optimum condition $30 \pm 2$ and $60 \pm 2 \mathrm{RH}$. Control insects were sprayed with only water instead of aqueous extracts and kept under the same condition. Insect mortality was recorded for various concentrations after $24 \mathrm{~h}, 48 \mathrm{~h}, 72 \mathrm{~h}$ and 1 week exposure.

\subsection{Statistical Analysis}

Mortality data were subjected to appropriate transformation prior analysis. Analysis of variance was used to check the significance of differences between mortality of various stages of test insects. The data were analyzed using multi-factor analysis of variance (ANOVA) in Statgraphics Centurion XV followed by Fischer's least significant difference (LSD) test to determine statistical differences between means of mortality at $\mathrm{P} \leq 0.05$. Data were Arcsine transformed to minimize the variability-to achieve normal distribution.

Mortality data was adjusted by Abbott's formula (Abbott, 1925) to estimate lethal concentration fifty $\left(\mathrm{LC}_{\mathbf{5 0}}\right)$ values and associated statistics were estimated by subjecting mortality data to the maximum likelihood program of probit analysis using SPSS software version 20.The impact of plant extracts were compared in terms of mortality and LC $_{50}$ values with time as the explanatory variable to evaluate mortality.

\section{RESULTS}

\subsection{Experiment 1: Insect identification through molecular based method (PCR)}

Two primer pairs were utilized for each species of Tribolium (castaneum and confusum) to ensure that at least one of them would have the potential to amplify the targeted gene. Agarose gel electrophoresis results indicated that the amplified species was T. castaneum. Consequently, the species specific primer pairs (Tcas-1) that have been designed to this study gave a clear band at $57^{\circ} \mathrm{C}$ with 120 base pair (bp). However, neither $T$. castaneum primer (Akk-1) nor T. confusum primers (TconfA and TconCOI) were capable of amplifying the DNA template (Figure 1A). Further, specific marker alongside negative control was set on the gel in order to determine the product size as well as the presence of target species. The process was repeated twice to test reliability of the new primer. Further, Species specific primers were also designed in this experiment to confirm the identity of Trogoderma species since specific primer can distinguish a certain species and due to the fact that all the three species of Trogoderma (granarium, variable and inclusum) morphologically similar to each other (Rees, 2004). The two specific primers for T. granarium (Tgr1, 169bp) and (Tgr2, 193bp) .Whereas, the other two specific primers were for $T$. inclusum (Tinc, 154bp) and T. variable named (Tvar, $235 \mathrm{bp}$ ). DNA-based method revealed the species as T.granarium due to 
the fact that both designed specific primers for this species showed clear bands on the gel (Figure 1B)

Additionally, the results confirmed that Oryzaephilus species found in the rice was surinamensis when the insect template screened with species specific primer named as (Osur-1, 223 bp). Though the other primer (Osur-2, $268 \mathrm{bp}$ ) designed for this study was not successful in amplifying the DNA template (Figure 1C). The DNA ladder was loaded in the first line so it can be compared with the product size of the designed primer.

(A)

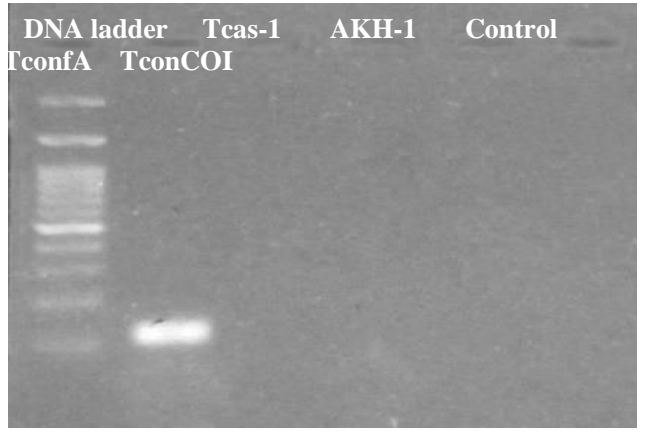

(B)

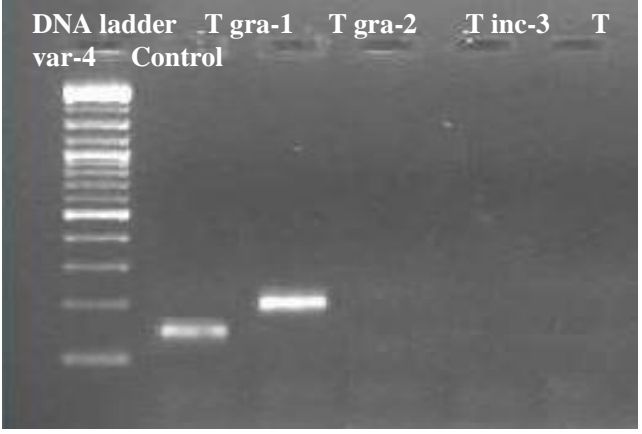

(C)

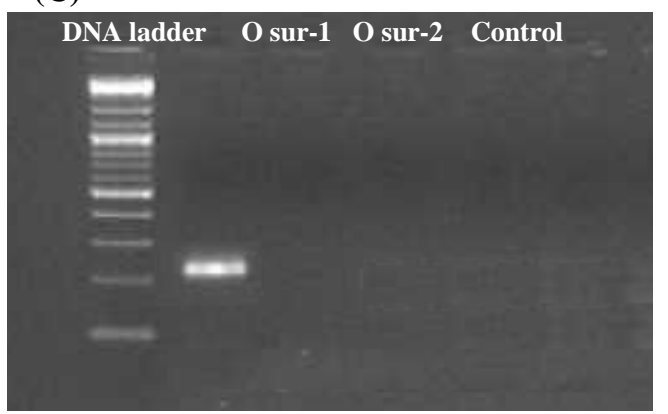

Figure 1. Gel plate of PCR product for (A) T. castaneum (B) $T$. granarium $(\mathrm{C}) O$. surinamensis via using species specific primers (primer labels correspond to those in Table (1)

\subsection{Experiment 2: Plant extracts to control examined insects}

3.2.1 Mortality of Tribolium castaneum: The laboratory experiment revealed that aqueous plant extracts significantly affected the mortality of Tribolium castaneum $\left(F_{(2,286)}=52.65, P<0.001\right)$. Thus, the three plant extracts varied in their toxicity impact and highest mortality $44.89 \%$ achieved via using eucalyptus extract (Figure 2A).

Moreover, mortality significantly influenced by exposure time $\left(F_{(3,286)}=196.93, P<0.001\right)$. As a result, fewer individuals survived when subjected for longer period of time to the extract. Highest mortality was obtained $55.12 \%$ after 7 days whereas lowest mortality was recorded after 1 day treatment $30.74 \%$ (Figure 2B).
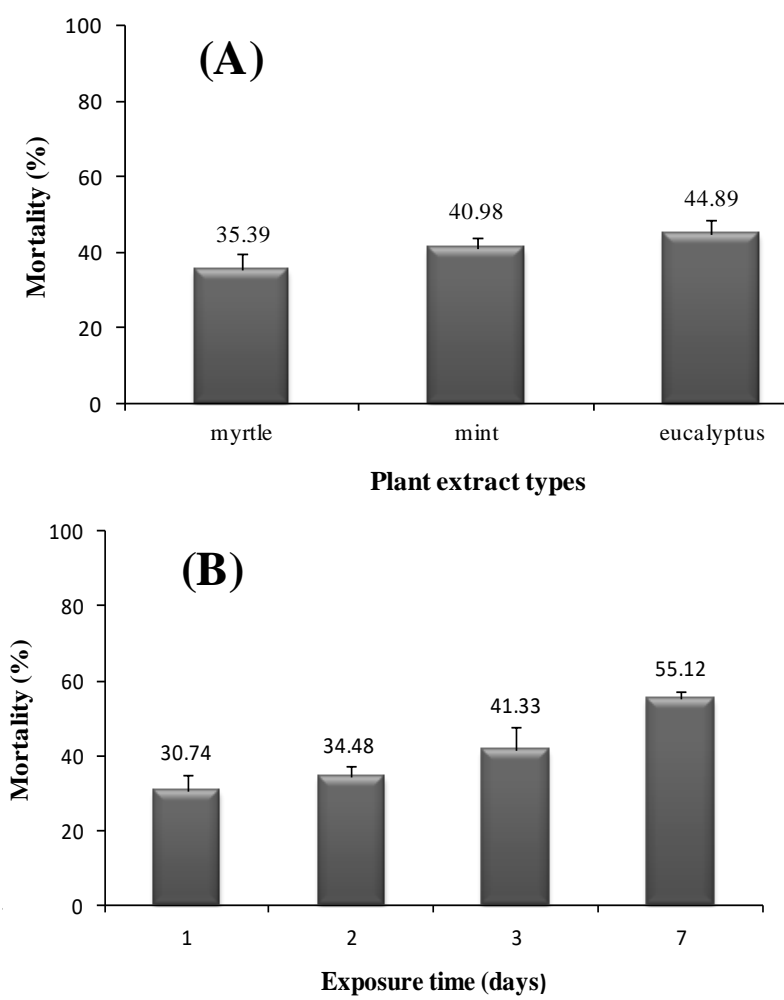

Figure 2. Percentage mortality of red flour beetle in relation to (A) plant extract types and (B) exposure times

Likewise, plant extract concentration $\left(F_{(3,286)}=1142.89, P\right.$ $<0.001)$ significantly affected adult mortality. The most efficient dose was $50000 \mathrm{ppm}$ which recorded $62.21 \%$, followed by $25000 \mathrm{ppm}$ and $12500 \mathrm{ppm}$ which recorded $52.22 \%$ \& 44.16 mortality respectively. Further, whether the insects were subjected to extracts with either black raisin or fig fruit didn't have any influence on adult mortality either separately $\left(F_{(1,286)}\right.$ $=0.22, P=0.64)$ or in interaction with other extract doses $\left(F_{(3,286)}\right.$ $=2.45, P=0.07)$.

In response to present data, mortality rate significantly influenced by the combination between plant extract dose and experimental time $\left(F_{(6,286)}=9.63, P<0.001\right.$, Figure 3$)$, maximum mortality was observed after 7 days treatment and were 82.95 , 68.54 and $57.35 \%$ for 50000,25000 and 12500 ppm aqueous concentration respectively. While, control treatment after 7 days recorded lowest mortality $11.64 \%$ when sprayed with water instead of aqueous plant extracts.

The interaction terms between plant extract type and doses were significant $\left(\left(F_{(6,286)}=7.05, P<0.001\right)\right.$. Maximum adult mortality reached at $50000 \mathrm{ppm}$ concentration for all the three plants. Thus, eucalyptus achieved $68.98 \%$ mortality which significantly differs from the other two extracts (mint \& myrtle) (Table 2).

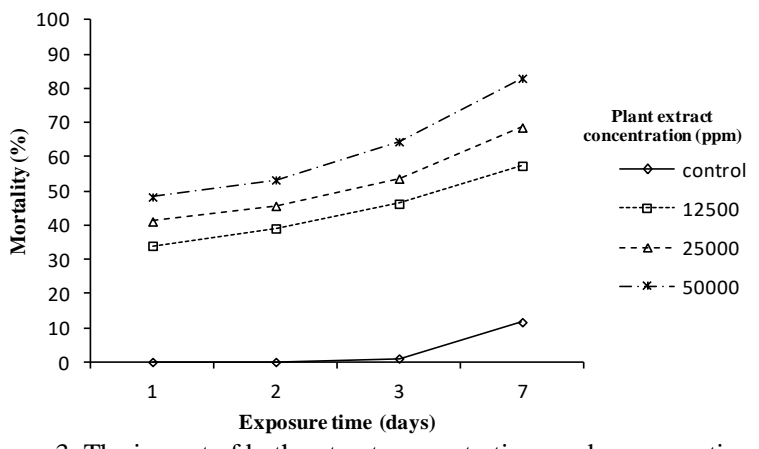

Figure 3. The impact of both extract concentrations and exposure times on percentage mortality of red flour beetle 
3.2.2 Mortality of Trogoderma granarium: Mortality was significantly affected by the type of aqueous extract $\left(F_{(2,287)}=75.05, P<0.001\right)$, mint aqueous extract resulted in highest adult mortality $42.76 \%$ followed by eucalyptus $41.34 \%$ which were not significantly differ from each other $\&$ while myrtle extract produced lowest $30.89 \%$ that significantly different from the other two plant extracts. Moreover, adult survival significantly influenced by exposure time $\left(F_{(3,287)}=158.69, P<0.001\right.$, Figure $\left.4 \mathrm{~A}\right)$. Hence, highest mortality $52.24 \%$ recorded after 7 days, whereas lowest was more than $27.41 \%$ after one day. Adult capability to escape from mortality was negatively in dependant to extract concentrations $\left(F_{(3,287)}=538.98, P<0.001\right)$. Thus, high dose $(50000 \mathrm{ppm})$ achieved $53.79 \%$ mortality but percentage mortality reduced with dosage reduction (Figure 4B). Whereas, Percentage mortality was not significantly affected by the types of dried fruits alone $\left(F_{(1,287)}=25.4, P=\right.$ 0.091 or via interaction with any other main factors in the experiment.
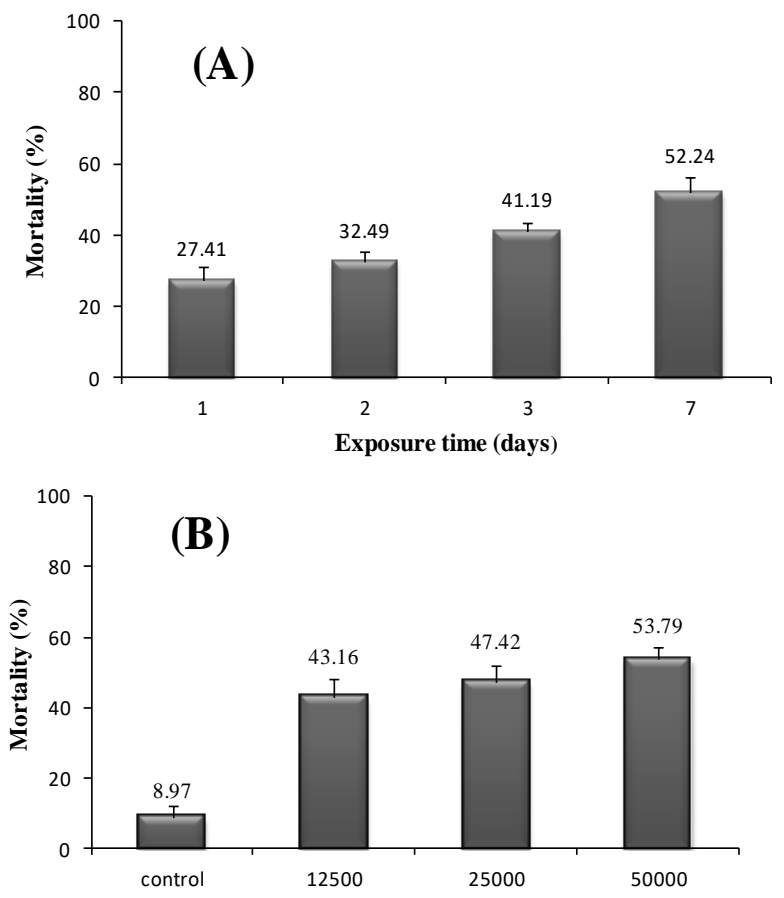

Plant extract concentration (ppm)

Figure 4. Percentage mortality of khapra beetle in response to (A) exposure times and (B) plant extract concentrations

Interactions term between not only plant extract concentration and exposure times were significant $\left(F_{(9,287)}=\right.$ $9.8, p<0.001$, Figure 5), but also survivorship influenced by both plant extract types and doses $\left(F_{(6,287)}=18.16, p<0.001\right.$, Table 2).

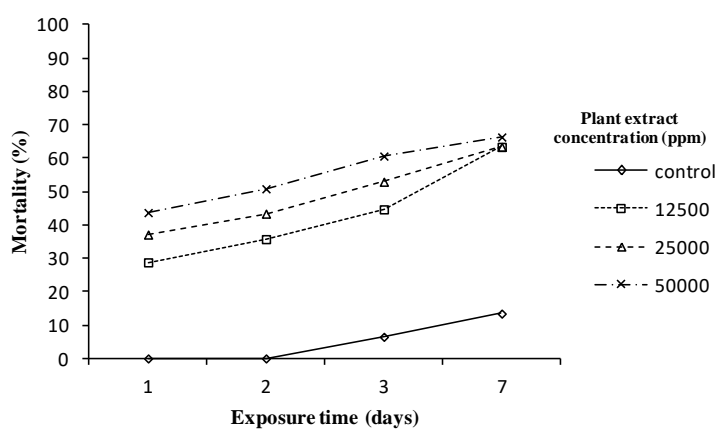

Figure 5. The impact of both extract concentrations and exposure times on percentage mortality of khapra beetle
3.2.3 Mortality of Oryzaephilus surinamensis: The laboratory test via utilizing different plant extracts significantly affected percentage mortality of sawtoothed grain beetle $\left(F_{(2,287)}\right.$ $=6.39, P<0.001)$. Adult treatment with eucalyptus aqueous extract achieved highest mortality $(30.29 \%)$ which didn't differ significantly from mint extract $(27.78 \%)$ (Figure 6A). In the same way, percentage mortality significantly influenced by plant concentrations $\left(F_{(3,287)}=323.86, P<0.001\right)$. Thus, highest percentage of mortality was 43.34 recorded by using $50000 \mathrm{ppm}$ (Figure 6B).
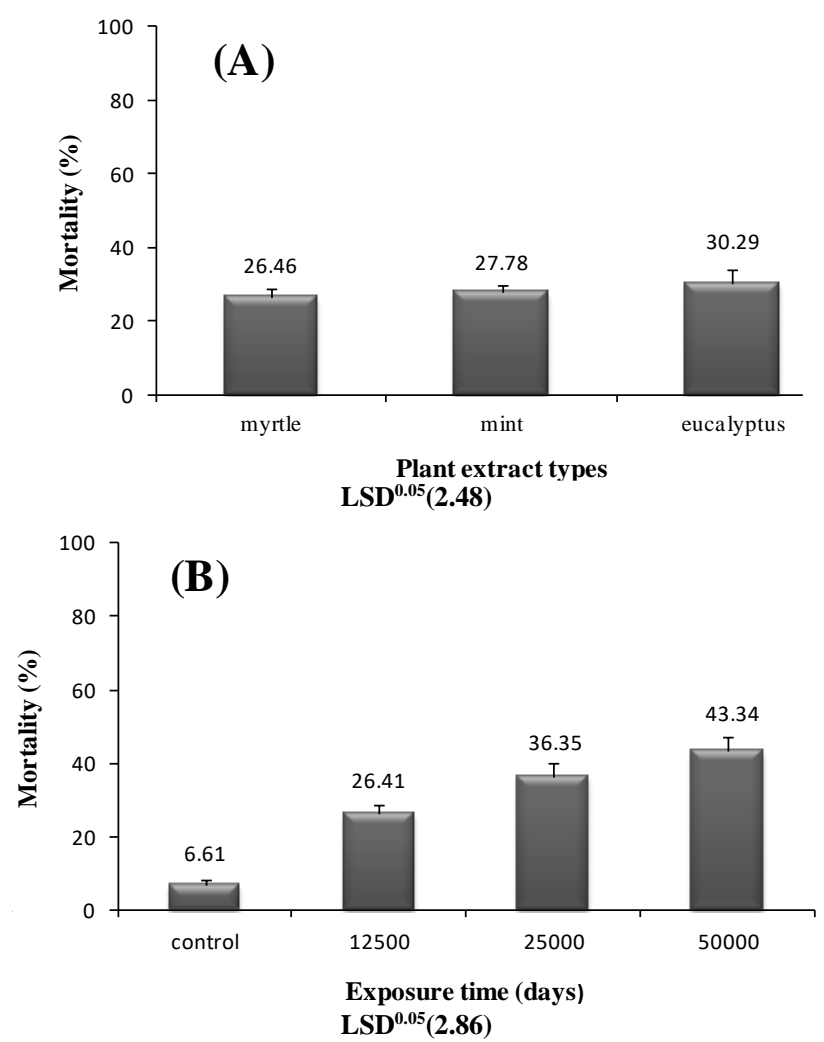

Figure 6. Percentage mortality of sawtoothed grain beetle in accordance to (A) plant extract types and (B) exposure times

In addition, the results obtained from the experiment indicated that not only the exposure duration alone had significant influence on survival $\left(F_{(3,287)}=97.62, P<0.001\right)$ but also via interaction with aqueous plant extract types $\left(\left(F_{(6,287)}=6.39, P\right.\right.$ $<0.002)$ had significant impact on adult mortality. Therefore, (44.64, 40.52 and 36.19) \% mortality were observed after 7 days on eucalyptus, mint and myrtle respectively (Figure 7).

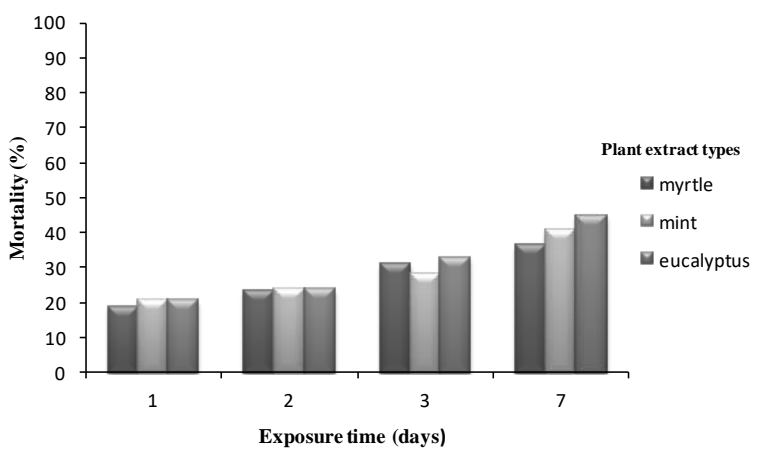

Figure 7. Percentage mortality of saw toothed grain beetle in relation to plant extract types and exposure times

The interaction between doses and extract types were significant $\left(F_{(3,287)}=323.86, P<0.001\right)$. Highest mortality $(46.16 \%)$ was recorded on eucalyptus at $50000 \mathrm{ppm}$ (Table 2). Moreover, when the three stored product insects treated with various plant extracts and doses the adult of red flour beetle was the most susceptible 
species followed by khapra beetle then saw-toothed grain beetle (Table 2).

Table (2): Comparison of the insecticidal activity between plant extract types and doses on percentage mortality of T. castaneum, T. granarium

\begin{tabular}{|c|c|c|c|c|c|}
\hline Plant extract & $\begin{array}{c}\text { Concentration } \\
(\mathbf{p p m})\end{array}$ & $\begin{array}{c}\text { Red flour } \\
\text { beetle }\end{array}$ & Khapra beetle & $\begin{array}{l}\text { Sawtoothed } \\
\text { grain beetle }\end{array}$ & Average \\
\hline \multirow{4}{*}{ Eucalyptus } & 0 & 4.98 & 8.85 & 9.49 & \multirow{4}{*}{38.84} \\
\hline & 12500 & 47.74 & 41.89 & 27.29 & \\
\hline & 25000 & 57.89 & 53.06 & 38.22 & \\
\hline & 50000 & 68.98 & 61.55 & 46.16 & \\
\hline \multirow{4}{*}{ Mint } & 0 & 2.64 & 9.49 & 8.82 & \multirow{4}{*}{37.61} \\
\hline & 12500 & 48.98 & 46.86 & 25.94 & \\
\hline & 25000 & 53.07 & 52.92 & 33.80 & \\
\hline & 50000 & 64.44 & 61.72 & 42.57 & \\
\hline \multirow{4}{*}{ Myrtle } & 0 & 1.87 & 8.57 & 1.53 & \multirow{4}{*}{30.91} \\
\hline & 12500 & 35.76 & 36.17 & 26.00 & \\
\hline & 25000 & 45.69 & 38.10 & 37.03 & \\
\hline & 50000 & 58.20 & 40.71 & 41.29 & \\
\hline Average & & 40.85 & 38.33 & 27.44 & \\
\hline LSD & & 2.53 & 4.62 & 2.66 & \\
\hline
\end{tabular}

3.2.4 Comparison between examined insect species on the basis of LC50 values: The toxicity of different plant extracts were evaluated via $\mathrm{LC}_{50}$ values on red flour beetle, khapra beetle and saw-toothed grain beetle, Table . The $\mathrm{LC}_{50}$ values revealed that saw-toothed grain beetle adults were more tolerant botanical insecticides than the other two species within various plant extracts and exposure times. Thus, higher doses must utilize in order to achieve 50\% mortality, followed by khapra and finally red flour beetle. The $\mathrm{LC}_{50}$ values of saw toothed grain beetle, khapra and red flour beetle ranged between 68713.87, 49607.16 and 44348.78 to $22763.48,276.55$ and 87.97 for the three species respectively (Table 3 ).

Table 3. The $\mathrm{LC}_{50}$ values in (ppm/days) using various aqueous plants on the adults of three stored product insects

\begin{tabular}{|c|c|c|c|c|c|}
\hline $\begin{array}{l}\text { Plant } \\
\text { extract }\end{array}$ & $\begin{array}{l}\text { Dried } \\
\text { fruit }\end{array}$ & $\begin{array}{l}\text { Time } \\
\text { (days) }\end{array}$ & $\begin{array}{l}\text { Redflour } \\
\text { beetle }\end{array}$ & $\begin{array}{l}\text { Khapra } \\
\text { beetle }\end{array}$ & $\begin{array}{l}\text { Saw-toothed } \\
\text { grain beetle }\end{array}$ \\
\hline \multirow{8}{*}{ Eucalyptus } & \multirow{4}{*}{$\begin{array}{l}\text { Black } \\
\text { raisin }\end{array}$} & 1 & 32936.93 & 40369.71 & 54562.63 \\
\hline & & 2 & 26881.96 & 33117.25 & 46623.76 \\
\hline & & 3 & 15918.70 & 24301.11 & 35703.78 \\
\hline & & 7 & 3887.25 & 10816.34 & 22763.48 \\
\hline & \multirow{4}{*}{ Fig } & 1 & 36412.21 & 43770.43 & 68713.87 \\
\hline & & 2 & 28552.75 & 33730.87 & 65655.19 \\
\hline & & 3 & 16454.51 & 25510.70 & 46233.39 \\
\hline & & 7 & 87.97 & 2532.38 & 42912.62 \\
\hline \multirow{8}{*}{ Mint } & \multirow{4}{*}{$\begin{array}{l}\text { Black } \\
\text { raisin }\end{array}$} & 1 & 29167.18 & 41148.83 & 64633.34 \\
\hline & & 2 & 24872.52 & 36602.86 & 61888.20 \\
\hline & & 3 & 21261.02 & 27278.95 & 59063.88 \\
\hline & & 7 & 11053.97 & 3144.76 & 45048.41 \\
\hline & \multirow{4}{*}{ Fig } & 1 & 34882.33 & 36129.12 & 63205.28 \\
\hline & & 2 & 29030.82 & 317116.5 & 57941.60 \\
\hline & & 3 & 24068.72 & 116971.5 & 48305.43 \\
\hline & & 7 & 11972.13 & 995.02 & 34330.48 \\
\hline
\end{tabular}

\begin{tabular}{|c|c|c|c|c|c|}
\hline \multirow{5}{*}{ Myrtle } & $\begin{array}{l}\text { Black } \\
\text { raisin }\end{array}$ & $\begin{array}{l}1 \\
2 \\
3 \\
7\end{array}$ & $\begin{array}{l}44348.78 \\
39600.78 \\
28730.72 \\
14726.86\end{array}$ & $\begin{array}{l}49607.16 \\
41544.77 \\
37220.31 \\
18421.43\end{array}$ & $\begin{array}{l}67814.80 \\
54076.79 \\
41008.472 \\
39016.78\end{array}$ \\
\hline & \multirow{4}{*}{ Fig } & 1 & 37338.90 & 37798.22 & 56359.29 \\
\hline & & 2 & 36628.66 & 27675.42 & 51807.99 \\
\hline & & 3 & 30972.84 & 17836.72 & 42023.97 \\
\hline & & 7 & 19199.63 & 276.55 & 28551.57 \\
\hline
\end{tabular}

\section{DISCUSSION}

The molecular data from this study reveal that specific primers can be used to confirm the identity of other similar morphologically indistinct species. Hence, species-specific PCR technique was efficient to separate Tribolium castaneum from $T$. confusum.. Similar to our finding, species-specific PCR technique was used for the separation of six species within Tribolium which were $T$. castaneum, T. confusum, $T$. destructor, T. madens, $T$. freemani and T. brevicornis of stored products (Zhang et al., 2016). Moreover, PCR-RFLP has been developed to distinguish Tribolium flour beetles based on a partial 28S rRNA gene sequence (Zhang et al., 2014). In addition, a study revealed that of out of 45 primer pairs designed only 19 pairs produced successful amplification when five strains of $T$. castaneum were screened to develop molecular genetic markers (Pai et al., 2003).

Likewise, the laboratory experiment was also able to develop specific primers for both Trogoderma granarium and Oryzaephilus surinamensis species. Three primers were sufficient to distinguish three species of Trogoderma. Hence, DNA polymorphic of $T$. grosuirium, $T$. variable \& $T$. glabrum was evaluated on the basis of molecular weight (Yulin et al., 
1999). Also, the sawtoothed grain beetle $O$. surinamensis along with the merchants grain beetle $O$. mercator were separated via using universal primers and species identity were confirmed as $O$. surinamensis after sequencing (Sorvari et al., 2012).

The aqueous plant extracts in this study showed clear insecticidal effects on the three examined stored product insects. The results of the present study are in agreement with some earlier studies Ciepielewska et al. (2005), who found that aqueous plant extracts prepared by pouring $10 \mathrm{~g}$ of macerate plant with $100 \mathrm{ml}$ water were capable of protecting stored commodities against $T$. castaneum. In addition, Ahmad et al. (2013) prepared (1:10) plant extracts via mixing $50 \mathrm{~g}$ powder of ginger Zingiber officinale with $500 \mathrm{ml}$ acetone as solvent. The results revealed that highest concentration of ginger was more toxic and reduced khapra population significantly inside wheat grains. Also, 83.3 and $73.3 \%$ mortality were achieved on sawtoothed grain beetle via using 0.125 dose after 2 and 1 week respectively within mint oil (Al-Jabar 2006).

The aqueous botanical extracts might affected the insects either via contact method through the cuticle or might disrupted the normal respiratory activities of these insects or could influenced the insect via feeding on treated dried fruits with the toxic extracts. Thus, the abovementioned methods alone or together resulted in the death of the test insects. Whereas, the respond of the three stored product insects vary towards the toxic impact of the aqueous extracts probably in accordance to chemical composition of the plants as well as insect susceptibility. The powerful impact of Eucalyptus camaldulensis might refer to the presence of various phytochemicals in the aqueous extract (e.g. tannins, saponins, glycosides, steroids and anthraquinones) (Sani et al., 2014). Therefore, the chemical ingredients of the plant have the potential to function as antimicrobial, insecticidal and insect repellent (Muell and Olugbade , 1996; Batish et al., 2008). In similar study, the toxicity of Eucalyptus camaldulensis leaves were examined against three stored product beetles (Tribolium castaneum, Sitophilus zeamais and Callosobruchus maculates). The botanical extracts exhibited more insecticidal toxicity against $T$. castaneum than to C. maculates and S. zeamais (Channoo et al., 2002). On the other hand, adult resistant might refer to the hard exoskeleton and less moisture content and however, $O$. surinamensis are small in size but consider as strong insect that has built up resistant to various insecticides and thus are often more difficult to kill and apply control methods on it in comparison with other stored product beetles (Heather \& Wilson, 1983; Walbank \& Collins 2003). Similar to our finding, the extracts of various plants; Azadirachta indica, Zanthoxylum zanthoxyloides, Anacardium occidentale and Moringa oleifera evoked high mortality effect on Sitophilus oryzae, Ryzopertha dominica and Oryzaephilus mercator but $O$. mercator was more tolerant to botanical extracts than $S$. oryzae and $R$. dominica (Kileke and Ogungbite, 2014). However, the finding of the current study is inconsistent with Al-Jabr (2006) who found that $O$. surinamensis is more susceptible to various oil plants than $T$. castaneum. As a result, when the toxicity of essential oil from various plants were tested complete mortality of saw toothed grain beetle was achieved at concentration $0.5 \%$ while required higher dose $1 \%$ to achieve complete mortality for red flour beetle. Similar to our finding Mohamad and Abdelgaleil (2008) examined the insecticidal activity of eight plant extracts on T. castaneum and the result indicated that Mentha microphylla $\left(\mathrm{LC}_{50}=0.01 \mathrm{mg} / \mathrm{cm}^{2}\right)$ exhibited highest insecticidal activity, followed by Eucalyptus camaldulensis $\left(\mathrm{LC}_{\mathbf{5 0}}=0.15 \mathrm{mg} / \mathrm{cm}^{2}\right)$. In a similar study conducted by Mamun et al. (2009) aqueous plant extracts of (bazna, ghora- neem, hijal, karanje, mahogoni and neem) utilized against red flour beetle with four different concentrations $(5.0,7.5,10.0$ and $12.5 \%)$ and various exposure times. The relative toxicity increased with an increase of both doses and exposure times. Thus, the result indicated that neem extract was the most toxic and the $\mathrm{LC}_{50}$ values were $(51.9,6.11$ and 4.05$)$ after $1,2 \& 3$ days respectively.

\section{CONCLUSIONS}

This study revealed that aqueous plant extracts possess toxic principles with significant insecticidal effects and could be a potential dried fruits protectant against various species of stored product. Further, among the tested plants, eucalyptus exhibited highest toxicity followed by mint and myrtle. Aqueous plant extracts can be utilized instead of alcoholic extract for insect treatment because not only it is feasible and cheap but also would not leave any unfavourable chemical residues on treated products. In addition, molecular based method consider as a vital complementary to the traditional method in order to achieve more precise identification

\section{ACKNOWLEDGEMENTS}

We thank the facilities provided by the Department of Plant Protection of Salahaddin University-Erbil. Also we would like to express our appreciation to both higher education laboratory \& biotechnology laboratory of Agriculture College. Special thanks to Kamaladdin Fatah and Qasim Marzani for their assistance during the study.

\section{REFERENCES}

Abbott, W. S. (1925). A method of computing the effectiveness of an insecticide. J. Econ. Entomol. 18: 265-267.

Abdulhay, H. S. (2012). Insecticidal Activity of Aqueous and Methanol Extracts of Apricot Prunus armeniaca L. Kernels in the Control of Tribolium confusum Duval (Coleoptera: Tenebrionidae). Al-Mustansiriyah J. Sci. 23(6): 7-18.

Ahmad, F., Sagheer, M., hammad, A., Rahman, S.M., and Hasan, M.U. (2013). Insecticidal activity of some plant extracts against Trogoderma granarium (E.). The Agriculturists. 11(1): 103111.

Alford, A. R., Cullen, J. A., Storch, R. H., and Bentley, M. D. (1987). Antifeedant activity of limonin against the Colorado potato beetle (Col. Chrysomelidae): Journal of Economic Entomology. 80 (5): 575 - 578.

AL-Jabr, A. M. (2006). Toxicity and repellency of seven plant essential oils to Oryzaephilus surinamensis (Coleoptera: Silvanidae) and Tribolium castaneum (Coleoptera: Tenebrioidae). Scientific Journal of King Faisal University (Basic and Applied Sciences). 7(1): 49-60.

Allen, G. C., Vergara, M. F., Krasnyanski, S., Kumar, S., and Thompson, W. F. (2006). A modiefied protocol for rapid DNA isolation from plant tissues using cetyltrimethyl ammonium bromide. Nature Protocol. 1(5): 2320-2325.

Batish, D. R., Singh, H. P., Kohli, R. K., and Kaur, S. (2008). Eucalyptus essential oil as a natural pesticide. Forest Ecology and Management, 258: P.2166-2174.

Benhalima, H., Chaudhry, M.Q., Mills, K.A., and Price, N.R. (2004). Phosphine resistance in stored-product insects collected from various grain storage facilities in Morocco. Journal of Stored Products Research. 40: 241-249

Bughio, F. M., and Wilkins, R. M. (2004). Influence of malathion resistance status on survival and growth of Tribolium castaneum (Coleoptera: Tenebrionidae), when fed on flour from insect resistant and susceptible grain rice cultivars. Journal of Stored Products Research. 40: 65-75.

Campbell J. F., Arthur F. H., and Mullen M. A. (2004). Insect management in food processing facilities. Adv. Food Nutr. Res. 48: 240- 295.

Carughi, A., Feeney, M.J., Kris-Etherton, P., Fulgoni, V., Kendall, C.W., Bulló, M., and Webb, D. (2016). Pairing nuts and dried fruit for cardio metabolic health. Nutrition journal. 15 (23): 1-13. 
Castalanelli, M.A., Mikac, K.M., Baker, A.M., Munyard, K., Grimm, M., and Groth, D.M. (2011). Multiple incursions and putative species revealed using a mitochondrial and nuclear phylogenetic approach to the Trogoderma variabile (Coleoptera: Dermestidae) trapping program in Australia. Bulletin of Entomological Research. 101(3): 333-343

Channoo, C., Tantakom, S., Jiwajinda, S. and Isichaikul, S. (2002). Fumigation toxicity of eucalyptus oil against three storedproduct beetles. Thai Journal of Agricultural Science. 35 : 265-272.

Chowdhry, M.A., Maqbool, A.,Mahmood, N., and Andkhalio, I. (1998). Performance of pure and mixed stands for biomass and grain yield in hexaploid wheat. Pak. J. Sc. 1: $145-147$

Ciepielewska, D., Kordan, B., and Nietupski, M. (2005). Effect of plant extracts on some stored-product insect pests. Polish Journal of Natural Sciences. 18 (1): 7-14.

Das, I., Kumar, G., and Shah, N. G. (2013). Microwave heating and alternative quarantine method for disinfestations of stored food grains. International Journal of Food Science. 1-13.

Gnanamanickam S.S. (2009). Rice and Its Importance to Human Life. Biological Control of Rice Diseases. London: Springer 8: 1-11

Gyurova, D., and Enikovam, R. (2014). Dried fruits-brief characteristics of their nutritional values. Authors own data for dietary fibbers content. Journal of Food and Nutrition Science. 2(4): 105-109.

Heather, N.W., and Wilson D. (1983). Resistance to fenitrothion in Oryzaephilus surinamensis (L.) (Coleoptera: Silvanidae) in Queensland. J. Aust. Entomol. Soc. 22, p. 210.

Hill, D.S. (1990). Pests of stored products and their control. Belhaven press, Boca Raton, FL, p, 274.

Khair, A.S.M. (2015). Studies on the Biology of the Red-flour beetle Tribolium castaneum Herbst.,(Coleoptera: Tenebrionidae) in different cereal flours (Doctoral dissertation, UOFK).

Kileke, K.D., and Ogungbite, O. C. (2014). Entomocidal activity of powders and extracts of four medicinal plants against Sitophilus oryzae (L), Oryzaephilus mercator (Faur) and Ryzopertha dominica (Fabr.). Bio. Sci. 7(1): 57-62.

Li, B., Predel, R., Newpert, S., Hauser, F., Tanaka, Y., Cazzamali, G., Williamson, M. Arakane, Y., Verleyen, P., Schoofs, L., Schachtner, J., Grimelikhuijzen, C., and Park, Y. (2008). Genomics, transcriptomics, and peptidomics of neuropeptids and protein hormones in the red flour beetle Tribolium castaneum. Genome Research. 18(1): 113122.

Mamun, M. S., Shahjahan, M. and Ahmad, M. (2009). Laboratory evaluation of some indigenous plant extracts as toxicants against red flour beetle, Tribolium castaneum Herbst. $J$. Bangladesh Agri. Univ. 7(1): 1-5.

Ming, Q., Wang, A., and Cheng, C. (2014). Molecular identification of Tribolium castaneum and T. confusum (Coleoptera: Tenebrionidae) using PCR-RFLP analysis. Journal of genetics.1-5.

Mishra, B. B., Tripathi, S. P., and Tripathi, C. P. (2012). Repellent effect of leaves essential oils from Eucalyptus globules (Mirtaceae) and Ocimum basilicum (Lamiaceae) against two major stored grain insect pests of coleopterans..Nature and Science. 10 (2): 50-54.

Mohamed, M. I., and Abdelgaleil, S. A. (2008). Chemical composition and insecticidal potential of essential oils from Egyptian plants against Sitophilus oryza (L.) (Coleoptera: Curculionidae) and Tribolium castaneum Herbst (Coleoptera: Tenebrionidae). Applied Entomology and Zoology. 43(4): 599-607.

Muell, A., and Olugbade, T.O. (1996). Chemical, biological and pharmacological properties of African medical plants. Journal of ethno pharmacology. 23: 99-118.

Nowaczyk, K.; Obrepalska-Steplowska, A.; Gawlak, M.; Throne, J. E.; Olejarski, P. and Nawrot, J. (2009). Molecular techniques for detection of Tribolium confusum infestations in stored products. J. Econ. Entomol. 102 (4): 1691-1695.

Pai, A., Sharakhov, I.V., Braginets, O., Costa, C., and Yan, G. (2003). Identification of microsatellite markers in the red flour beetle, Tribolium castaneum. Molecular Ecology Notes. 3(3): 425-427.

Poehlman, J.M., and Sleper, D. A. (1995). Breeding Field Crops. 4th ed. Ames, IA, USA: Iowa State University Press.

Rahman, S., Biswas, S. K., Barman, N. C., and Ferdous, T. (2016). Plant extracts as selective pesticide for integrated pest management. J. Biotec. Res. 2(1): 6-10.

Rees, D. P. (2004). Insects of stored products. Csiro Publishing. 1-181.

Risha, E., Mel nahal,A. K., and Schmidt, G. H. (1990). Toxicity of Acorus calamus $\mathrm{L}$ oil to the immature stages of some stored-products Coleoptra. Journal of Stored-product Research. 26(3): 133 137.

Ronald, P. (2011). Plant genetics, sustainable agriculture and global food security. Genetics. 188 (1): 11-20.

Rozen, S., and Skaletsky, H. (2000). Primer3 on the www for general users and for biologist programmers. Methods in molecular biology. 132: 365-386. Source code available at http://frodo.wi.mit.edu/primer3/.

Sani, I., Abdulhamid, A., and Bello, F. (2014). Eucalyptus camaldulensis: Phytochemical composition of ethanolic and aqueous of the leaves, stem- bark, root, fruits and seeds. Journal of Scientific and Innovative Reasearch. 3(5): p.523-526.

Sarmamy, A. G., Hashim, H., and Sulayman, A. (2011). Insecticidal effects of some aqueous plant extracts on the control of Khapra beetle Trogoderma granarium Evert. In International Conference on Chemical, Biological and Environment Sciences. Bangkok. 288-292.

Sharma, S., and Choudhary, A. K. (2008). Storage pests management. New Delhi, Mahman Publication House. 1-148.

Singh, S., and Prakash, S. (2015). Effect of temperature and humidity on the culture of Tribolium castaneum Herbst (Coleoptera: Tenebrionidae) in the laboratory. International Journal of Scientific and Research Publication. 5 (7): 1-6.

Soni, N., Mehta, S., Satpathy, G., and Gupta, R. K. (2014). Estimation of nutritional, phytochemical, antioxidant and antibacterial activity of dried fig (Ficus carica). Journal of Pharmacognosy and Phytochemistry. 3(2): 158-165.

Sorvari, J., Härkönen, S. K., and Vesterinen, E. J. (2012). First record of an indoor pest sawtoothed grain beetle Oryzaephilus surinamensis (Coleoptera: Silvanidae) from wild outdoor wood ant nest. Entomologica Fennica. 23(2): 69-71.

Stephen, J. P. (2003). A new measure of uptake: desorption of untreated posphine from susceptible and resistant strains of Tribolium castaneum (Herbst) (Coleoptera: Tenebrionidae). J. Stored Prod. Res. 39: 507: 520.

Susha, C., and Karnavar, G K. (1993). Effect of azadirachtm on vitelogernc deocyte developement mtrpgpderma grananym Everts. Indian Journal of Expenmental Biology. 31(2): 180 190.

Tayoub, G., Abu Alnaser, A., and Ghanem, I. (2012). Fumigant activity of leaf essential oil from Myrtus communis L. against the khapra beetle. Int J, Med, Arom, Plants. 2(1): .207-213.

Varshney R. K., Balyan H. S., and Langridge, P. (2006). Wheat. Genome mapping and molecular breeding in plants. Cereals and millets. Kole Ch. (ed.). Berlin, Heidelberg, 1: 79-134.

Wallbank, B.E., and Collins, P.J. (2003). Recent changes in resistance to grain protectants in eastern Australia. p. 66-70. In: Proc. Aust. Postharvest Technical Conference "Stored Ggrain in Australia 2003" (E.J. Wright, M.C. Webb, E. Highley, eds.). Canberra, Australia. p 253.

Walter, V. E. (1990). Stored product pests. Handbook of Pest Control Story.1-67.

Wani, S.H., and Sah, S.K., (2014). Biotechnology and abiotic stress tolerance in rice. $J$ Rice Res 2. p.e105.

Weston, P. A., and Rattlingourd P. A. (2000). Progeny production by Tribolium castaneum (Coleoptera: Tenebrionidae) and Oryzaephilus surinamensis (Coleoptera: Silvanidae) on maize previously infested by Sitotroga cerealella (Lepidoptera: Gelechiidae). J. Econ. Entomol. 93: 533-535.

Yousif, S. M. H. (2012). The Uses of Microwave Radiation to Control some insects of stored rice and its effects on qualities. M.Sc. thesis, University of Mosul, Education College .1-118.

Yulin, A, Caihua, D, Hongbing, Z., and Guoyao, J. (1999). RAPD assessment of three sibling species of Trogoderma Dejean (Coleoptera: Dermestidae). In: Jin Z, Liang Q, Liang Y,Tan $\mathrm{X}$ and Guan L, editors. Proceedings of the 7th International Working Conference on Stored-Product Protection, 14-19 October 1998; Beijing, China. Chengdu, China. 1755-757. 
Zeigler, R.S., and Mohanty, S. (2010). Support for international agricultural research: current status and future challenges. New biotechnology. 27(5): 565-572.

Zettler, J.L., and Cuperus, G.W. (1990). Pesticide resistance in Tribolium castaneum (Coleoptera: Tenebrionidae) and Rhyzopertha dominica (Coleoptera: Bostrichidae) in wheat. J. Econ. Entomol. 83: 1677-1681.

Zhang, H.S., Feng, Z.J., and Cheng, C. (2014). Molecular identification of Tribolium castaneum and T. confusum based on PCR-RFLP analyses of $28 \mathrm{~S}$ rRNA gene. $J$. Environ. Entomol. 2:.008

Zhang, T., Wang, Y. J., Guo, W., Luo, D., Wu, Y., Kučerová, Z., Stejskal, V., Opit, G., Cao, Y., Li, F. J., and Li, Z. H. (2016). DNA barcoding, species-specific PCR and realtime PCR techniques for the identification of six Tribolium pests of stored products. Scientific Reports. 6: $1-11$.

Zuzana, S., Edita, G., and Ernest, S., (2009). Chemical composition and nurittional quality of wheat grain. Acta Chimica Slovaca. 2(1): 115- 138. 